These findings seem to confirm that prognosis is improved by early diagnosis, which can be improved if routine examinations are carried out at intervals not exceeding six months. Probably a mass $x$-ray unit concentrating on men aged 55 and over smoking 15 cigarettes a day could salvage four-year survivors at a cost of only $£ 300$ each. Every 1,000 films taken would pick up a potential four-year survivor.

This study was possible only with the help of many people. We are grateful to them all, particularly the staffs of the Registrar General's Office and of the National Health Service executive councils in England and Wales, the South Metropolitan Cancer Registry, the S.E. and S.W. London Mass $X$-ray Services, the medical and surgical staff of the Brompton Hospital, and the staff of the Brook Thoracic Surgical Unit. We thank the S.E. and S.W.
Metropolitan Regional Hospital Boards for support from research funds. We thank Miss G. Whitworth for invaluable help with drafting this paper and for tabulations; Miss J. Higgs, Miss $M$. Ravenscroft, and Miss A. Taylor for help in the follow-up; and Mr. E. Uztups for the illustration.

\section{REFERENCES}

Barrett, N. R. (1958). In Cancer, vol. 4, edited by R. W. Raven, p. 301.

Boucot, K. R., Cooper, D. A., and Weiss, W. (1961). Ann. intern. Med., $54,363$.

Brett, G. Z. (1966). Proc. roy. Soc. Med., 59, 1208.

Heasman, M. A., and Lipworth, L. (1966). Accuracy of Certification of Cause of Death. H.M.S.O., London.

Nash, F. A. (1959). 3rd International Congress of Medical Radiography, Stockholm, 1958, p. 306. Rome.

\title{
Renal Tubular Acidosis of Pyelonephritis with Renal Stone Disease
}

\author{
M. COCHRAN,* M.B., CH.B.; M. PEACOCK,* M.B., CH.B., M.R.C.P.; D. A. SMITH,* M.B., B.S., B.SC., M.R.C.P.ED. \\ B. E. C. NORDIN,* M.D., PH.D., F.R.C.P.
}

Brit. med. F., 1968, 2, 721-729

Renal tubular acidosis was first described by Butler, Wilson, and Farber (1936) and subsequently by Albright, Consolazio, Coombs, Sulkowitch, and Talbot (1940). The essential feature of the syndrome as described by these workers was a hyperchloraemic metabolic acidosis associated with an inappropriately alkaline urine. The condition has often been considered to be congenital (Pitts, Schulte, and Smith, 1955 ; Huth, Webster, and Elkinton, 1960), and is sometimes associated with other tubular defects (Jackson and Linder, 1953). An important feature is a tendency to nephrocalcinosis and/or renal stone formation, which may be the presenting disorder, but renal tubular acidosis is generally considered to be a relatively rare cause of renal stone disease.

Wrong and Davies (1959) emphasized that the essential lesion of renal tubular acidosis was a failure of the distal tubule to produce a urine of normal acidity and simplified the diagnosis by developing a short ammonium chloride loading test. With this test they showed an acidifying defect not only in a group of cases with hyperchloraemic acidosis, but also in three patients with unexplained nephrocalcinosis without acidosis, and in several cases of renal disease of various causes.

In recent years increasing attention has been paid to the behaviour of the renal tubule in pyelonephritis (Brod, 1956 ; Kleeman, Hewitt, and Guze, 1960 ; Kaitz, 1961), but there has been little systematic examination of the renal handling of hydrogen ion in this condition. Several authors have noted a failure to conserve bicarbonate in cases of pyelonephritis, but they have tended to distinguish between this disorder and renal tubular acidosis as the term is generally used (Schwartz and Relman, 1957 ; Lathem, 1958). Others have stated that renal tubular acidosis may be a complication of pyelonephritis (Albright and Reifenstein, 1948 ; Wrong, 1965), but very few documented cases have actually been reported.

In the course of studying patients with renal stone disease we have routinely performed the short acid load test of Davies and Wrong (1957) and have found a substantial number of stone patients unable to acidify their urine to a normal degree. A feature of all these cases is the presence of active upper urinary tract infection, and this, combined with the absence of any

* Medical Research Council, Mineral Metabolism Research Unit, the General Infirmary, Leeds. other underlying condition, leads us to believe that the condition in these patients is acquired as a result of chronic pyelonephritis. The present paper gives the results obtained in 24 such cases collected over a period of five years and compares them with a further 24 patients with renal stone disease and pyelonephritis who could produce a urine of normal acidity.

\section{Clinical Material}

Eighteen patients with renal stone disease (out of about 600 tested) were unable to acidify their urine to $\mathrm{pH} 5.4$ (Davies and Wrong, 1957). All of them had a chronic urinary tract infection. From this group of 18 cases we have excluded five because of associated cystinuria (two cases), primary hyperoxaluria (one case), Cushing's syndrome (one case), and steroid therapy (one case).

Twelve additional patients who presented with kidney stones and infection were found to have medullary sponge kidneys on radiological and histological evidence and four of these failed to acidify their urine. They were not included in the present study.

Eleven patients from a similar clinic in Glasgow, selected on identical criteria, were added to the Leeds group to make a total of 24 cases (group A). In none of these 24 cases was there evidence of urinary tract obstruction, which is known to cause an acidification defect of the urine (Berlyne, 1961).

For comparison with this series we chose the first 24 of the total of 63 Leeds patients with pyelonephritis and renal stone disease who could acidify their urine below $p H 5.4$ (group B).

The diagnosis of pyelonephritis was made if at least three of the following criteria were fulfilled: a convincing history of recurrent urinary tract infections, repeated pyuria with positive bacterial cultures in midstream specimens of urine, radiological changes on intravenous pyelography (Edwards, 1965), histological evidence (Cotran, 1965), and a positive prednisone provocation test (Little and de Wardener, 1962). In no case was there a history of analgesic abuse (Dawborn, Fairley, Kincaid-Smith, and King, 1966) or evidence of hypertensive renal disease.

The stones were graded as staghorn, medium, and small. The term "staghorn calculus" referred to any stone which 
filled the entire renal pelvis, whether or not it formed a complete cast of the caliceal system. Medium stones included those judged too large to enter the ureter but smaller than a staghorn, and small stones were those which could probably pass spontaneously. Stones often recurred after surgical removal, and the total number of staghorn or medium-sized calculi formed by each patient was easily assessed radiologically. The number of small stones was more difficult to estimate, especially in the patient who passed them frequently, and the figures given in some of the cases are only approximate.

\section{Methods}

The acid load test was performed exactly as described by Davies and Wrong (1957), the diagnosis of renal tubular acidosis being made when the subject failed to lower the urinary $\mathrm{pH}$ to 5.4. Renal concentrating power was determined after at least 18 hours of fluid deprivation by measuring the specific gravity and in most cases the osmolality (Miles, Paton, and de Wardener, 1954).

All measurements were made on fresh 24-hour urine samples collected, with streptomycin and chloramphenicol as preservatives. Titratable acidity was measured in $5-\mathrm{ml}$. aliquots of urine diluted in $15 \mathrm{ml}$. of distilled water by titration with
$0.1 \mathrm{~N}$ sodium hydroxide to $\mathrm{pH} 7.4$, urine $\mathrm{pH}$ by an E.I.L. $\mathrm{pH}$ meter, ammonia by the method of Chaney and Marbach (1962), citrate by the method of Ettinger, Goldbaum, and Smith (1952), and calcium and creatinine by AutoAnalyzer techniques (Nordin and Smith, 1965).

A fasting blood sample with a corresponding one-hour urine collection was obtained from every patient. Serum sodium and potassium were measured by flame photometry and chloride by the E.E.L. chloride titrator. Serum bicarbonate, calcium, phosphorus, and creatinine were determined by AutoAnalyzer (Nordin and Smith, 1965). Alkaline phosphatase was determined by the method of Wootton and King (1953). Urinary calcium, phosphorus, and creatinine were measured as described above. Urine amino-acids were examined by paper chromatography, a morning urine sample being used. Stone analyses were performed as described by Nordin and Smith (1965).

\section{Clinical Results}

The clinical data in the 24 patients who failed to acidify their urine (group A) are shown in Table I. The corresponding data from the patients who could produce a urine of normal acidity (group B) are shown in Table II.

Table I.-Group A : Clinical Data on 24 Patients who Failed to Acidify Their Urine

\begin{tabular}{|c|c|c|c|c|c|c|c|c|c|c|c|c|c|c|c|c|c|}
\hline \multicolumn{3}{|c|}{ Patient } & \multicolumn{6}{|c|}{ Criteria for Pyelonephritis } & \multicolumn{9}{|c|}{ Progress of Stone Disease } \\
\hline \multirow{3}{*}{$\begin{array}{l}\text { Case } \\
\text { No. }\end{array}$} & \multirow{3}{*}{ Age } & \multirow{3}{*}{ Sex } & \multirow{3}{*}{$\begin{array}{l}\text { Length } \\
\text { of } \\
\text { History } \\
\text { (Years) }\end{array}$} & \multirow{3}{*}{ M.S.U. } & \multirow{2}{*}{\multicolumn{2}{|c|}{$\begin{array}{c}X \text {-Ray } \\
\text { Changes }\end{array}$}} & \multirow{3}{*}{$\begin{array}{l}\text { His- } \\
\text { tology }\end{array}$} & \multirow{3}{*}{$\begin{array}{c}\text { Predni- } \\
\text { sone } \\
\text { Provo- } \\
\text { cation } \\
\text { Test } \\
\end{array}$} & \multirow{3}{*}{$\begin{array}{l}\text { Length } \\
\text { of } \\
\text { History } \\
\text { (Years) }\end{array}$} & \multirow{2}{*}{\multicolumn{2}{|c|}{ 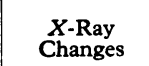 }} & \multirow{2}{*}{\multicolumn{3}{|c|}{ Nos. and Types of Stones }} & \multicolumn{3}{|c|}{ Stone Composition } \\
\hline & & & & & & & & & & & & & & & \multirow{2}{*}{$\begin{array}{l}\text { Calcium } \\
\text { Oxalate }\end{array}$} & \multirow{2}{*}{$\begin{array}{c}\text { Calcium } \\
\text { Phosphate }\end{array}$} & \multirow{2}{*}{$\begin{array}{l}\text { Magnesium } \\
\text { Ammonium } \\
\text { Phosphate }\end{array}$} \\
\hline & & & & & Right & Left & & & & Right & Left & Staghorn & Medium & Small & & & \\
\hline $\begin{array}{r}1 \\
2 \\
3 \\
4 \\
* 5 \\
* 6 \\
* 7 \\
* 8 \\
9 \\
10 \\
11 \\
12 \\
13 \\
14 \\
* 15 \\
* 16 \\
* 17 \\
* 18 \\
* 19 \\
20 \\
21 \\
* 22 \\
* 23 \\
+24\end{array}$ & $\begin{array}{l}16 \\
27 \\
30 \\
35 \\
39 \\
41 \\
43 \\
45 \\
49 \\
54 \\
58 \\
58 \\
60 \\
77 \\
33 \\
33 \\
44 \\
44 \\
58 \\
57 \\
59 \\
68\end{array}$ & $\begin{array}{l}\mathrm{F} \\
\mathrm{F} \\
\mathrm{F} \\
\mathrm{F} \\
\mathrm{F} \\
\mathrm{F} \\
\mathrm{F} \\
\mathrm{F} \\
\mathrm{F} \\
\mathrm{F} \\
\mathrm{F} \\
\mathrm{F} \\
\mathrm{F} \\
\mathrm{F} \\
\mathrm{M} \\
\mathrm{M} \\
\mathrm{M} \\
\mathrm{M} \\
\mathrm{M} \\
\mathrm{M} \\
\mathrm{M} \\
\mathrm{M} \\
\mathrm{M} \\
\mathrm{M}\end{array}$ & $\begin{array}{r}15 \\
7 \\
7 \\
7 \\
16 \\
20 \\
5 \\
3 \\
6 \\
33 \\
29 \\
30 \\
19 \\
9 \\
17 \\
12 \\
11 \\
21 \\
4 \\
14 \\
31 \\
7 \\
15 \\
6\end{array}$ & $\begin{array}{l}+ \\
+ \\
+ \\
+ \\
+ \\
+ \\
+ \\
+ \\
+ \\
+ \\
+ \\
+ \\
+ \\
+ \\
+ \\
+ \\
+ \\
+ \\
+ \\
+ \\
+ \\
+\end{array}$ & $\begin{array}{l}+ \\
+ \\
+ \\
+ \\
+ \\
+ \\
+ \\
+ \\
+ \\
+ \\
+ \\
+ \\
+ \\
+ \\
+ \\
+ \\
+ \\
+ \\
+ \\
+ \\
+ \\
+\end{array}$ & $\begin{array}{l}+ \\
+ \\
+ \\
+ \\
+ \\
+ \\
+ \\
+ \\
+ \\
+ \\
+ \\
+ \\
+ \\
+ \\
+ \\
+ \\
+ \\
+ \\
+ \\
+ \\
+ \\
+ \\
+ \\
+\end{array}$ & $\begin{array}{l} \pm \\
\pm \\
\pm \\
\pm \\
\pm \\
\pm \\
\pm \\
\pm \\
\pm \\
\pm \\
\pm \\
\pm \\
\pm \\
\pm \\
\pm\end{array}$ & $\begin{array}{l} \pm \\
\pm \\
\pm \\
\pm \\
\pm \\
\pm \\
\pm \\
\overline{ } \\
\pm \\
\pm \\
\pm \\
\pm \\
\pm \\
\pm\end{array}$ & $\begin{array}{r}1 \\
5 \\
2 \\
1 \\
6 \\
60 \\
5 \\
10 \\
6 \\
1 \\
20 \\
2 \\
6 \\
9 \\
17 \\
4 \\
11 \\
12 \\
1 \\
10 \\
29 \\
8 \\
10 \\
1\end{array}$ & $\begin{array}{l}+ \\
+ \\
+ \\
+ \\
+ \\
+ \\
+ \\
+ \\
+ \\
+ \\
+ \\
+ \\
+ \\
+ \\
+ \\
+ \\
+ \\
+ \\
+ \\
+ \\
+\end{array}$ & $\begin{array}{l}+ \\
+ \\
+ \\
+ \\
+ \\
+ \\
+ \\
+ \\
+ \\
+ \\
+ \\
+ \\
+ \\
+ \\
+ \\
+ \\
+ \\
+ \\
+ \\
+\end{array}$ & $\begin{array}{l}1 \\
4 \\
4 \\
2 \\
0 \\
0 \\
1 \\
0 \\
2 \\
1 \\
3 \\
0 \\
2 \\
0 \\
2 \\
2 \\
2 \\
0 \\
1 \\
1 \\
2 \\
0 \\
0 \\
1\end{array}$ & $\begin{array}{r}0 \\
0 \\
0 \\
0 \\
1 \\
1 \\
0 \\
7 \\
0 \\
1 \\
1 \\
2 \\
0 \\
10 \\
0 \\
2 \\
0 \\
0 \\
1 \\
0 \\
0 \\
2 \\
2 \\
1\end{array}$ & $\begin{array}{r}1 \\
0 \\
0 \\
0 \\
20 \\
5 \\
0 \\
20 \\
0 \\
3 \\
0 \\
0 \\
0 \\
0 \\
20 \\
10 \\
0 \\
4 \\
6 \\
0 \\
1 \\
10 \\
0 \\
4 \\
0\end{array}$ & 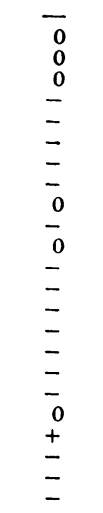 & $\begin{array}{l} \pm \\
\pm \\
\pm \\
\pm \\
\pm \\
\pm \\
\pm \\
\pm \\
\pm \\
\pm \\
\pm \\
\pm \\
\pm \\
\pm \\
\pm \\
=\end{array}$ & $\begin{array}{l} \pm \\
+ \\
\pm \\
\pm \\
\pm \\
\pm \\
\pm \\
\pm \\
\pm \\
\pm \\
\pm \\
\\
\pm \\
\pm \\
\pm \\
\pm \\
\end{array}$ \\
\hline
\end{tabular}

* Glasgow cases. + Paget's disease. + Result positive. 0 Result negative. - Result not available.

TABle II.-Group B : Clinical Data on 24 Patients who Could Acidify Their Urine

\begin{tabular}{|c|c|c|c|c|c|c|c|c|c|c|c|c|c|c|c|c|c|}
\hline \multicolumn{3}{|c|}{ Patient } & \multicolumn{6}{|c|}{ Criteria for Pyelonephritis } & \multicolumn{9}{|c|}{ Progress of Stone Disease } \\
\hline \multirow{3}{*}{$\begin{array}{l}\text { Case } \\
\text { No. }\end{array}$} & \multirow{3}{*}{ Age } & \multirow{3}{*}{ Sex } & \multirow{3}{*}{$\begin{array}{l}\text { Length } \\
\text { of } \\
\text { History } \\
\text { (Years) }\end{array}$} & \multirow{3}{*}{ M.S.U. } & \multirow{2}{*}{\multicolumn{2}{|c|}{$\begin{array}{c}X \text {-Ray } \\
\text { Changes }\end{array}$}} & \multirow{3}{*}{\begin{tabular}{|} 
His- \\
tology
\end{tabular}} & \multirow{3}{*}{$\begin{array}{c}\text { Predni- } \\
\text { sone } \\
\text { Provo- } \\
\text { cation } \\
\text { Test }\end{array}$} & \multirow{3}{*}{$\begin{array}{c}\text { Length } \\
\text { of } \\
\text { History } \\
\text { (Years) }\end{array}$} & \multirow{2}{*}{\multicolumn{2}{|c|}{$\begin{array}{c}X \text {-Ray } \\
\text { Changes }\end{array}$}} & \multirow{2}{*}{\multicolumn{3}{|c|}{ Nos. and Types of Stones }} & \multicolumn{3}{|c|}{ Stone Composition } \\
\hline & & & & & & & & & & & & & & & \multirow{2}{*}{$\begin{array}{c}\text { Calcium } \\
\text { Oxalate }\end{array}$} & \multirow{2}{*}{$\begin{array}{l}\text { Calcium } \\
\text { Phosphate }\end{array}$} & \multirow{2}{*}{$\begin{array}{c}\text { Magnesium } \\
\text { Ammonium } \\
\text { Phosphate }\end{array}$} \\
\hline & & & & & Right & Left & & & & Right & Left & Staghorn & Medium & Small & & & \\
\hline $\begin{array}{l}25 \\
26 \\
27 \\
28 \\
29 \\
30 \\
31 \\
32 \\
33 \\
34 \\
35 \\
36 \\
37 \\
38 \\
39 \\
40 \\
41 \\
42 \\
43 \\
44 \\
45 \\
46 \\
47 \\
48\end{array}$ & $\begin{array}{l}19 \\
22 \\
24 \\
29 \\
37 \\
42 \\
45 \\
48 \\
49 \\
51 \\
52 \\
52 \\
54 \\
55 \\
56 \\
59 \\
60 \\
73 \\
32 \\
50 \\
55 \\
60 \\
62 \\
70\end{array}$ & $\begin{array}{c}\mathbf{F} \\
\mathbf{F} \\
\mathbf{F} \\
\mathbf{F} \\
\mathbf{F} \\
\mathbf{F} \\
\mathbf{F} \\
\mathbf{F} \\
\mathbf{F} \\
\mathbf{F} \\
\mathbf{F} \\
\mathbf{F} \\
\mathbf{F} \\
\mathbf{F} \\
\mathbf{F} \\
\mathbf{F} \\
\mathbf{F} \\
\mathbf{F} \\
\mathbf{M} \\
\mathbf{M} \\
\mathbf{M} \\
\mathbf{M} \\
\mathbf{M} \\
\mathbf{M}\end{array}$ & $\begin{array}{r}2 \\
4 \\
1 \\
8 \\
24 \\
1 \\
3 \\
26 \\
8 \\
4 \\
20 \\
6 \\
3 \\
1 \\
3 \\
3 \\
1 \\
5 \\
2 \\
6 \\
3 \\
26 \\
21 \\
2\end{array}$ & $\begin{array}{l}+ \\
+ \\
+ \\
+ \\
+ \\
+ \\
+ \\
+ \\
+ \\
0 \\
+ \\
+ \\
+ \\
0 \\
+ \\
+ \\
+ \\
+ \\
+ \\
0 \\
+ \\
+ \\
+ \\
+\end{array}$ & $\begin{array}{l}+ \\
+ \\
+ \\
+ \\
+ \\
+ \\
+ \\
0 \\
+ \\
+ \\
+ \\
+ \\
0 \\
+ \\
+ \\
0 \\
0 \\
+ \\
+ \\
+ \\
0 \\
+ \\
+ \\
+\end{array}$ & $\begin{array}{l}+ \\
+ \\
+ \\
+ \\
+ \\
0 \\
+ \\
+ \\
0 \\
+ \\
+ \\
+ \\
+ \\
0 \\
+ \\
+ \\
+ \\
+ \\
+ \\
+ \\
+ \\
+ \\
+ \\
+\end{array}$ & $\begin{array}{l}z \\
= \\
= \\
\pm \\
= \\
= \\
= \\
= \\
= \\
\pm \\
\pm \\
+ \\
+ \\
+ \\
\pm \\
= \\
-\end{array}$ & $\begin{array}{l} \pm \\
= \\
= \\
\overline{0} \\
\overline{ \pm} \\
\pm \\
\pm \\
= \\
\pm \\
= \\
\overline{+} \\
\pm \\
\pm \\
\pm \\
= \\
\pm\end{array}$ & $\begin{array}{r}10 \\
1 \\
1 \\
4 \\
24 \\
1 \\
3 \\
8 \\
6 \\
4 \\
20 \\
1 \\
3 \\
1 \\
2 \\
8 \\
1 \\
5 \\
1 \\
5 \\
4 \\
26 \\
3 \\
1\end{array}$ & $\begin{array}{c}+ \\
0 \\
0 \\
0 \\
+ \\
+ \\
+ \\
0 \\
+ \\
0 \\
+ \\
+ \\
0 \\
+ \\
+ \\
0 \\
0 \\
+ \\
+ \\
+ \\
0 \\
+ \\
0 \\
+\end{array}$ & $\begin{array}{l}+ \\
+ \\
+ \\
+ \\
+ \\
0 \\
+ \\
+ \\
0 \\
+ \\
+ \\
+ \\
+ \\
0 \\
+ \\
+ \\
+ \\
+ \\
+ \\
+ \\
+ \\
+ \\
+ \\
+\end{array}$ & $\begin{array}{l}1 \\
1 \\
0 \\
1 \\
2 \\
1 \\
1 \\
0 \\
0 \\
0 \\
1 \\
0 \\
0 \\
1 \\
0 \\
1 \\
0 \\
1 \\
0 \\
0 \\
0 \\
0 \\
1 \\
1\end{array}$ & $\begin{array}{r}16 \\
0 \\
1 \\
0 \\
2 \\
0 \\
2 \\
2 \\
1 \\
0 \\
0 \\
1 \\
1 \\
0 \\
2 \\
0 \\
1 \\
0 \\
0 \\
2 \\
0 \\
3 \\
0 \\
0\end{array}$ & $\begin{array}{r}0 \\
0 \\
0 \\
7 \\
5 \\
0 \\
1 \\
0 \\
0 \\
3 \\
5 \\
1 \\
0 \\
2 \\
0 \\
0 \\
0 \\
1 \\
20 \\
1 \\
4 \\
3 \\
1 \\
1\end{array}$ & $\begin{array}{c}0 \\
+ \\
- \\
0 \\
+ \\
- \\
+ \\
= \\
= \\
+ \\
- \\
+ \\
+ \\
- \\
+ \\
+ \\
+ \\
0 \\
- \\
-\end{array}$ & $\begin{array}{l}+ \\
+ \\
+ \\
+ \\
+ \\
\pm \\
\pm \\
= \\
0 \\
+ \\
\pm \\
= \\
+ \\
+ \\
+ \\
\pm \\
-\end{array}$ & $\begin{array}{l}+ \\
+ \\
- \\
+ \\
0 \\
- \\
+ \\
- \\
= \\
\overline{0} \\
- \\
0 \\
0 \\
= \\
\overline{+} \\
0 \\
\overline{+} \\
- \\
-\end{array}$ \\
\hline
\end{tabular}


Group A consisted of 14 women and 10 men whose ages ranged from 16 to 77 years. Group B consisted of 18 women and 6 men with an age range of 19 to 73 years. All the patients gave a history of repeated urinary tract infection, and in only three cases, all on antibiotic therapy, were midstream urine specimens sterile.

The history of infection ranged from 3 to 33 years in group A and from 1 to 26 years in group B, but the mean length of history was 18 and 8 years respectively. Bilateral radiological changes of pyelonephritis were present in all group A cases, but in only 16 out of 24 in group B were buth kidneys affected. The predominant infecting organisms were Escherichia coli and Proteus species, and these occurred with equal frequency in both groups.

The relation between infection, impaired acidifying power, and stone formation is illustrated by the progress of some of the Leeds patients in group A who have been carefully followed up. When Case 1 was first seen she had infected urine but could acidify to $\mathrm{pH} 5$. One year later there was failure of acidifying power, and bilateral stones had appeared. Case 9 had known urinary tract infection for several years before the appearance of a stone. When Cases 10 and 20 were first seen there was a defect of acidification and only small stones were present, but these rapidly grew to staghorn calculi over a period of about one year in association with persistent infection. Cases 2 and 3 had had bilateral pyelolithotomies, but there was rapid recurrence of the staghorn calculi in the presence of untreated infection (Figs. 1 and 2). Subsequent pyelolithotomies in these patients and also in Cases 4, 10, 12, and 20 were followed by energetic chemotherapy for several months from the time of operation, and though renal function remained

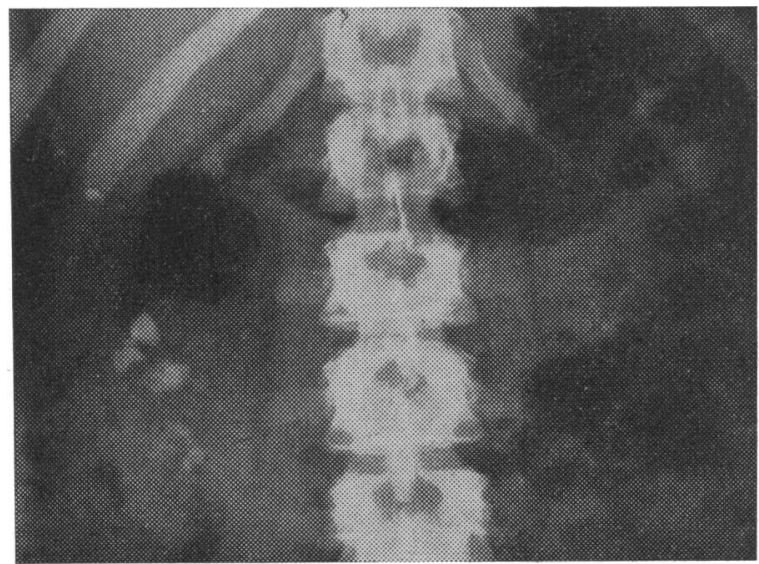

FIG. 1.-Plain abdominal $x$-ray film from Case 3 with renal tubular acidosis in January 1964, one year after bilateral pyelolithotomies; showing numerous calculi in the right kidney and at least one calculus in the left kidney.

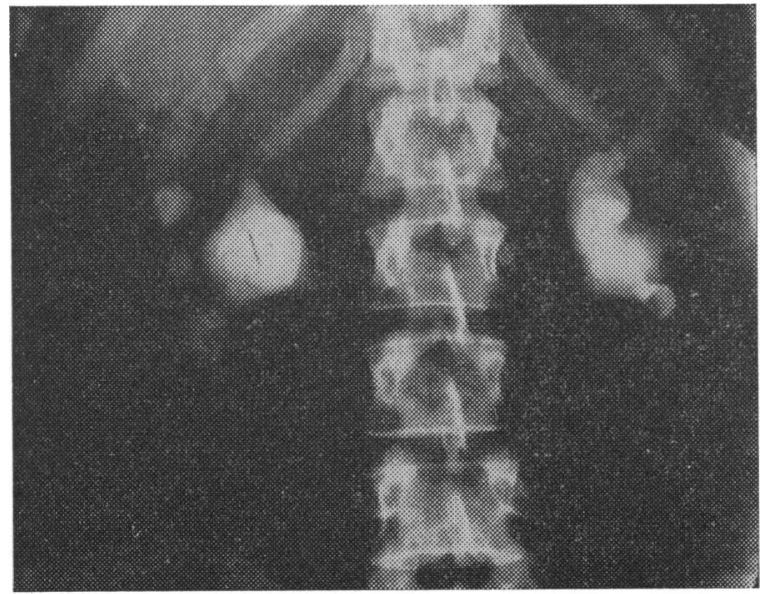

FIG 2.-Plain abdominal $x$-film from Case 3 in January 1965 to show tne growth of staghorn calculi on both side in one year. essentially unchanged stones have not re-formed over the period of follow-up (6 to 18 months) (Fig. 3). In Case 11 infection was not controlled after a right nephrectomy and left pyelolithotomy, and staghorn calculus rapidly reappeared over a period of four months. No further stone growth appears to have taken place in Cases 9, 13, 21, and 24 while on chemotherapy, though pyuria has continued. Case 14 was not followed up.

The history of kidney stone ranged from 1 to 29 years in group $\mathrm{A}$ and from 1 to 26 years in group B, with mean values of eight and six years respectively. Bilateral stones were present in 23 group A cases but in only 11 group B cases. The 24 patients in group A produced a total of 31 staghorn and at least 31 medium-sized calculi, whereas among the 24 cases in group B there were only 13 staghorn but 34 medium-sized stones. Passage of small calculi and fragments was common in both groups.

Stones were available for analysis on seven of the patients from group A and 12 in group B. All stones from group A were of the mixed calcium phosphate and magnesium ammonium phosphate variety, and in only one case was calcium oxalate present as well. Six of the stones analysed from group B were composed of mixed calcium phosphate and magnesium ammonium phosphate, two of these also containing calcium oxalate. Of the remaining six one was pure calcium oxalate, one pure calcium phosphate, and the rest mixed oxalate and phosphate.

\section{Biochemical Results}

\section{Urinary Acid Excretion}

The biochemical data are shown in Tables III and IV. The lowest urine $p H$ values after the acid load are given. The groups are separated at a urine $p H$ of 5.4 by definition. Half the patients in group A could not lower their urine $p H$ to 6.2 ; the remainder could not acidify below $\mathrm{pH}$ 5.5. In group $\mathrm{B}$, though a $p \mathrm{H}$ of 5.4 or less was reached in all cases, only half

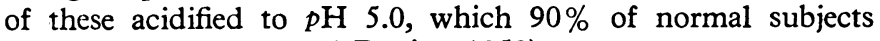
can achieve (Wrong and Davies, 1959).

The titratable acid and ammonium values and their ratios are given in Tables III and IV. Titratable acid excretion was below $10 \mathrm{mEq}$ per 24 hours in over half the group $\mathrm{A}$ cases but in only three of group B. Ammonium excretion was variable but tended to be high in group $A$. The ratio of titratable acid to ammonium was less than 0.4 in 17 of group $A$ cases and over this value in 22 of group B cases. Ammonium excretion tended to be higher relative to urine $\mathrm{pH}$ and to creatinine clearance in group A than in group B (Figs. 4 and 5).

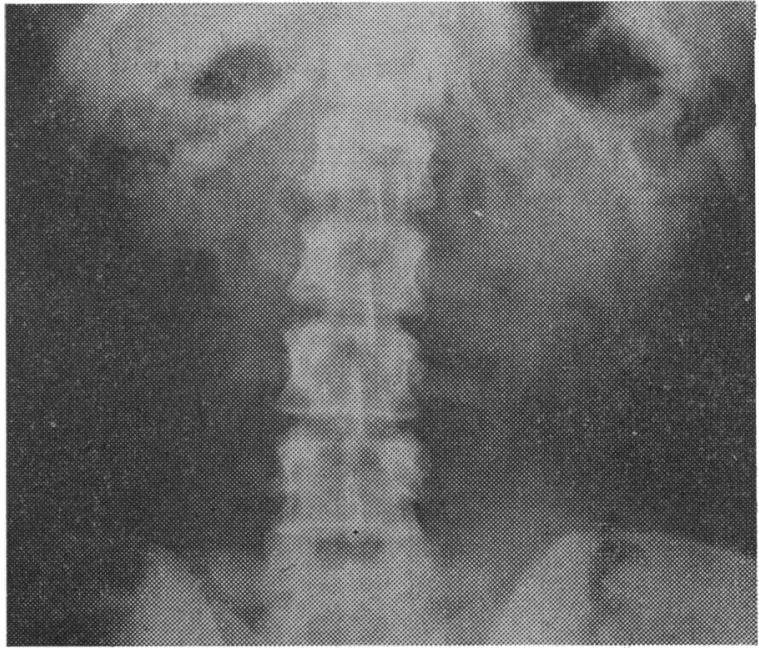

FIG. 3.-Plain abdominal $x$-ray film from Case 3 in July 1967 , 18 months after bilateral pyelolithotomies, to show complete absence of stone recurrence after continuous antibiotic therapy 


\section{Concentrating Power}

The maximum urine specific gravity was reduced in both groups. It was clearly subnormal in all but one of the group A cases, but in group B seven patients reached a normal value of 1022 .

\section{Creatinine Clearance}

The creatinine clearance tended to be lower in group $A$ than in group B, being below $70 \mathrm{ml} . / \mathrm{min}$. in 16 group $\mathrm{A}$ cases but in only seven group B cases.

\section{Serum Electrolytes}

Serum sodium values fell within the normal range in both series. Serum chloride was above the upper normal limit of
$108 \mathrm{mEq} / 1$. in six group A cases and in one group B case. Serum bicarbonate was below the lower normal limit of 25 $\mathrm{mEq} / \mathrm{l}$. in 16 group $\mathrm{A}$ and 12 group $B$ cases. The two patients in group A with the lowest plasma bicarbonate values (Cases 13 and 21) both had hyperchloraemia, but in the groups as a whole there was no significant correlation (direct or inverse) between the plasma chloride and bicarbonate levels. Serum potassium values fell within the normal range in virtually all the cases in both groups.

\section{Calcium and Phosphorus Metabolism}

Serum calcium values were below $9 \mathrm{mg} . / 100 \mathrm{ml}$. in only three group A and two group B cases. None of the patients had hypercalcaemia.

Serum phosphorus values were below $2.5 \mathrm{mg} . / 100 \mathrm{ml}$. in four group A and two group B cases. Hyperphosphataemia

TABle III.-Biochemical Data of Group A Patients

\begin{tabular}{|c|c|c|c|c|c|c|c|c|c|c|c|c|c|c|c|c|c|c|c|c|}
\hline \multirow{3}{*}{ 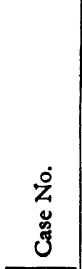 } & \multicolumn{6}{|c|}{ Renal Function } & \multicolumn{10}{|c|}{ Serum Values } & \multicolumn{4}{|c|}{ Renal Excretion } \\
\hline & \multirow{2}{*}{ 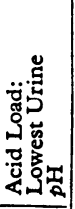 } & 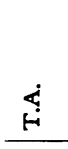 & $\begin{array}{l}\text { 量 } \\
\text { 尊 } \\
\text { 息 }\end{array}$ & 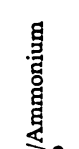 & 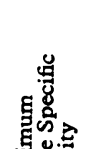 & :ै. & 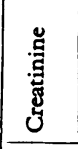 & క్ & 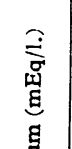 & 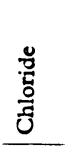 & 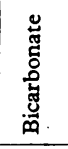 & 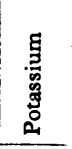 & 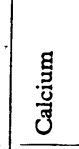 & 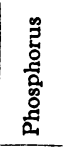 & \multirow{2}{*}{ 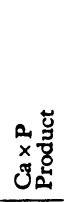 } & \multirow{2}{*}{ 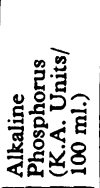 } & తై & $2^{2}$ & & $\begin{array}{l}\stackrel{8}{3} \\
\stackrel{3}{3}\end{array}$ \\
\hline & & & & & & 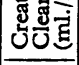 & (mg./1 & $\infty$ & 㞼 & & $\mathrm{mEq} / \mathrm{s}$ & & $(\mathrm{mg} . / 1$ & $00 \mathrm{ml})$. & & & (mg. $/ 1$ & I.G.F. & 00 & \\
\hline $\begin{array}{r}1 \\
1 \\
3 \\
3 \\
4 \\
* 5 \\
* 6 \\
* 7 \\
* 8 \\
9 \\
10 \\
11 \\
12 \\
13 \\
14 \\
* 15\end{array}$ & $\begin{array}{l}6.1 \\
5.7 \\
6.5 \\
5.8 \\
6.4 \\
5.5 \\
55.8 \\
5.5 \\
6.5 \\
5.5 \\
5.8 \\
6.4 \\
65.9 \\
6.4 \\
6.4 \\
6.4 \\
6.9 \\
6.8 \\
6.0 \\
6.5 \\
6.0 \\
6.4\end{array}$ & $\begin{array}{r}29 \\
9 \\
2 \\
17 \\
4 \\
16 \\
8 \\
4 \\
10 \\
29 \\
9 \\
1 \\
0 \\
5 \\
18 \\
13 \\
2 \\
2 \\
14 \\
18 \\
11 \\
14 \\
9 \\
2\end{array}$ & $\begin{array}{l}48 \\
20 \\
28 \\
37 \\
50 \\
33 \\
42 \\
44 \\
67 \\
59 \\
23 \\
62 \\
28 \\
10 \\
63 \\
49 \\
45 \\
50 \\
58 \\
48 \\
47 \\
48\end{array}$ & $\begin{array}{l}0.600 \\
0.45 \\
0.07 \\
0.46 \\
0.09 \\
0.49 \\
0.19 \\
0.09 \\
0.15 \\
0.49 \\
0.39 \\
0.02 \\
0.00 \\
0.50 \\
0.29 \\
0.27 \\
0.04 \\
0.04 \\
0.25 \\
0.38 \\
0.24\end{array}$ & 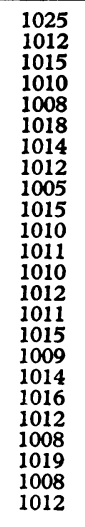 & $\begin{array}{c}85 \\
45 \\
40 \\
33 \\
445 \\
65 \\
48 \\
70 \\
70 \\
97 \\
32 \\
60 \\
15 \\
22 \\
38 \\
50 \\
50 \\
112 \\
72 \\
86 \\
39 \\
100 \\
52 \\
69\end{array}$ & $\begin{array}{l}0.9 \\
1.6 \\
1.4 \\
1.8 \\
1.1 \\
1.0 \\
1.6 \\
1.0 \\
1.2 \\
0.8 \\
2.1 \\
1.5 \\
3.5 \\
2.1 \\
3.6 \\
2.4 \\
2.3 \\
1.2 \\
1.3 \\
1.3 \\
2.5 \\
1.0 \\
1.2 \\
2.2\end{array}$ & $\begin{array}{c}18 \\
51 \\
45 \\
40 \\
46 \\
32 \\
44 \\
52 \\
28 \\
40 \\
60 \\
53 \\
100 \\
58 \\
68 \\
47 \\
44 \\
26 \\
35 \\
28 \\
65 \\
28 \\
41 \\
52\end{array}$ & $\begin{array}{l}142 \\
137 \\
138 \\
133 \\
146 \\
136 \\
136 \\
136 \\
144 \\
143 \\
143 \\
140 \\
133 \\
133 \\
135 \\
141 \\
141 \\
1147 \\
134 \\
139 \\
136\end{array}$ & $\begin{array}{l}100 \\
105 \\
1019 \\
99 \\
111 \\
110 \\
1002 \\
108 \\
105 \\
106 \\
106 \\
109 \\
102 \\
104 \\
105 \\
106 \\
106 \\
106 \\
115 \\
104\end{array}$ & \begin{tabular}{|l}
22 \\
23 \\
23 \\
25 \\
25 \\
25 \\
18 \\
18 \\
25 \\
22 \\
22 \\
22 \\
22 \\
11 \\
11 \\
17 \\
25 \\
24 \\
24 \\
26 \\
13
\end{tabular} & 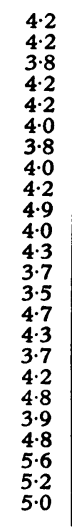 & \begin{tabular}{|c|}
10.0 \\
9.8 \\
10.2 \\
10.1 \\
99.2 \\
99.6 \\
78.6 \\
10.7 \\
10.2 \\
99.7 \\
99.3 \\
89.2 \\
99.8 \\
99.8 \\
99.9 \\
99.4 \\
99.6 \\
99.5
\end{tabular} & $\begin{array}{l}3.7 \\
2.9 \\
3.3 \\
3.4 \\
2.4 \\
3.0 \\
2.9\end{array}$ & $\begin{array}{l}37 \\
28 \\
34 \\
34 \\
22 \\
29 \\
20 \\
17 \\
30 \\
34 \\
34 \\
31 \\
64\end{array}$ & $\begin{array}{r}8 \\
6 \\
6 \\
14 \\
8 \\
6 \\
17 \\
7 \\
7 \\
7 \\
6 \\
6 \\
8 \\
15 \\
12 \\
12\end{array}$ & $\begin{array}{l}0 \\
0 \\
0 \\
0 \\
0 \\
0 \\
0\end{array}$ & & $\begin{array}{r}107 \\
154 \\
99 \\
133 \\
100 \\
248 \\
57 \\
157 \\
164 \\
273 \\
220 \\
206 \\
20 \\
58 \\
70 \\
35 \\
80 \\
440 \\
58 \\
385 \\
95 \\
196 \\
75 \\
73\end{array}$ & $\begin{array}{l}0.39 \\
0.15 \\
0.20 \\
0.00 \\
0.19 \\
0.22 \\
0.17 \\
0.00\end{array}$ \\
\hline
\end{tabular}

* Glasgow cases. † Paget's disease.

Table IV.-Biochemical Data of Group B Patients

\begin{tabular}{|c|c|c|c|c|c|c|c|c|c|c|c|c|c|c|c|c|c|c|c|c|}
\hline \multirow{3}{*}{$\begin{array}{l}\dot{0} \\
\ddot{0} \\
\dot{0} \\
0\end{array}$} & \multicolumn{6}{|c|}{ Renal Function } & \multicolumn{10}{|c|}{ Serum Values } & \multicolumn{4}{|c|}{ Renal Excretion } \\
\hline & \multirow{2}{*}{ 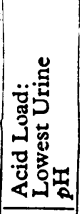 } & $\stackrel{\leftrightarrow}{\leftrightarrow}$ & 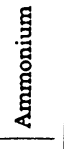 & 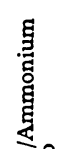 & 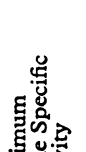 & : & 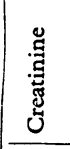 & 巴 & 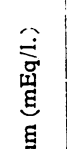 & 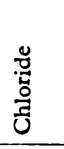 & 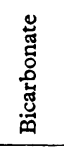 & 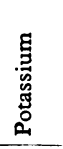 & 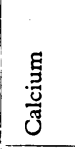 & 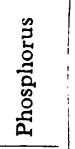 & \multirow{2}{*}{ 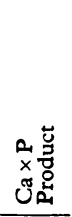 } & \multirow{2}{*}{ 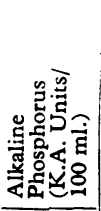 } & ชึ & $\alpha^{m}$ & 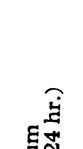 & 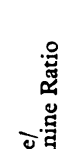 \\
\hline & & \multicolumn{2}{|c|}{$\begin{array}{c}\text { (mEq/24 hr. } \\
\text { Urine) }\end{array}$} & 递曷 & 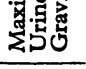 & 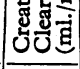 & \multicolumn{2}{|c|}{ (mg./100 ml.) } & 䄈 & \multicolumn{3}{|c|}{$\mathrm{mEq} / 1$} & \multicolumn{2}{|c|}{ (mg./100 ml.) } & & & \multicolumn{2}{|c|}{ (mg./100 ml. G.F. } & 苟 & 预 \\
\hline $\begin{array}{l}25 \\
26 \\
27 \\
28 \\
29 \\
30 \\
31 \\
32 \\
33 \\
34 \\
35 \\
36 \\
37 \\
38 \\
39 \\
40 \\
41 \\
42 \\
43 \\
44 \\
45 \\
46 \\
47 \\
48\end{array}$ & $\begin{array}{l}5.3 \\
5.2 \\
4.8 \\
5.2 \\
5.1 \\
5.3 \\
4.9 \\
4.8 \\
5.0 \\
5.3 \\
5.1 \\
4.6 \\
4.8 \\
4.7 \\
4.8 \\
5.0 \\
4.9 \\
4.6 \\
5.2 \\
4.7 \\
5.3 \\
5.4 \\
5.4 \\
4.9\end{array}$ & $\begin{array}{l}22 \\
10 \\
18 \\
3 \\
17 \\
8 \\
16 \\
14 \\
13 \\
18 \\
12 \\
30 \\
29 \\
11 \\
33 \\
18 \\
18 \\
15 \\
43 \\
38 \\
3 \\
20 \\
36 \\
24\end{array}$ & $\begin{array}{l}34 \\
23 \\
45 \\
59 \\
12 \\
17 \\
28 \\
18 \\
31 \\
28 \\
57 \\
28 \\
26 \\
22 \\
22 \\
33 \\
10 \\
17 \\
40 \\
53 \\
16 \\
30 \\
29 \\
18\end{array}$ & $\begin{array}{l}0.65 \\
0.44 \\
0.41 \\
0.05 \\
1.30 \\
0.50 \\
0.57 \\
0.77 \\
0.42 \\
0.65 \\
2.10 \\
1.07 \\
1.12 \\
0.50 \\
1.50 \\
0.55 \\
1.80 \\
0.88 \\
1.10 \\
0.71 \\
0.19 \\
0.67 \\
1.24 \\
1.32\end{array}$ & $\begin{array}{l}1018 \\
1014 \\
1023 \\
1018 \\
1016 \\
1024 \\
1011 \\
1010 \\
1024 \\
1020 \\
1016 \\
1021 \\
1020 \\
1018 \\
1018 \\
1020 \\
1012 \\
1020 \\
1022 \\
1022 \\
1026 \\
1012 \\
1023 \\
1013\end{array}$ & \begin{tabular}{|r|}
78 \\
106 \\
95 \\
130 \\
80 \\
70 \\
50 \\
80 \\
108 \\
105 \\
55 \\
84 \\
70 \\
65 \\
56 \\
80 \\
43 \\
50 \\
140 \\
80 \\
126 \\
77 \\
90 \\
65
\end{tabular} & $\begin{array}{l}1.3 \\
0.7 \\
0.7 \\
0.9 \\
1.5 \\
0.9 \\
0.9 \\
0.9 \\
0.8 \\
1.0 \\
1.1 \\
0.9 \\
0.9 \\
1.0 \\
1.3 \\
1.0 \\
1.2 \\
1.4 \\
1.0 \\
1.3 \\
1.0 \\
1.3 \\
1.0 \\
1.0\end{array}$ & $\begin{array}{l}25 \\
25 \\
20 \\
35 \\
35 \\
22 \\
35 \\
20 \\
28 \\
27 \\
29 \\
28 \\
35 \\
33 \\
43 \\
22 \\
28 \\
30 \\
20 \\
30 \\
29 \\
42 \\
35 \\
37\end{array}$ & $\begin{array}{l}135 \\
140 \\
142 \\
137 \\
139 \\
139 \\
140 \\
137 \\
138 \\
137 \\
135 \\
142 \\
140 \\
141 \\
139 \\
137 \\
139 \\
141 \\
140 \\
139 \\
137 \\
136 \\
139\end{array}$ & $\begin{array}{r}98 \\
108 \\
100 \\
108 \\
102 \\
103 \\
111 \\
102 \\
107 \\
100 \\
100 \\
100 \\
105 \\
101 \\
108 \\
108 \\
96 \\
105 \\
107 \\
107 \\
103 \\
98 \\
104 \\
101\end{array}$ & $\begin{array}{l}27 \\
21 \\
24 \\
24 \\
23 \\
24 \\
20 \\
25 \\
27 \\
26 \\
23 \\
29 \\
25 \\
24 \\
27 \\
25 \\
21 \\
24 \\
24 \\
28 \\
21 \\
25 \\
27 \\
29\end{array}$ & 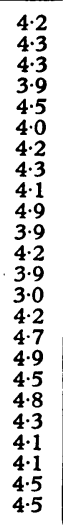 & \begin{tabular}{|r|}
10.7 \\
10.0 \\
10.0 \\
9.2 \\
9.4 \\
10.1 \\
9.0 \\
9.9 \\
9.5 \\
10.0 \\
9.8 \\
9.5 \\
9.8 \\
9.6 \\
10.3 \\
9.1 \\
9.5 \\
8.9 \\
10.2 \\
9.9 \\
10.4 \\
10.8 \\
8.9 \\
9.8
\end{tabular} & $\begin{array}{l}3.7 \\
3.6 \\
3.1 \\
3.7 \\
3.2 \\
2.9 \\
3.3 \\
3.3 \\
3.7 \\
4 \cdot 2 \\
2.8 \\
2 \cdot 6 \\
3.9 \\
3.3 \\
3.7 \\
3 \cdot 6 \\
3 \cdot 6 \\
2.4 \\
3.1 \\
3.1 \\
3.0 \\
2.4 \\
2.9 \\
3 \cdot 2\end{array}$ & $\begin{array}{l}40 \\
20 \\
31 \\
34 \\
30 \\
29 \\
34 \\
33 \\
35 \\
42 \\
27 \\
25 \\
38 \\
32 \\
38 \\
33 \\
34 \\
21 \\
32 \\
31 \\
27 \\
26 \\
26 \\
31\end{array}$ & $\begin{array}{r}8 \\
10 \\
11 \\
9 \\
8 \\
4 \\
6 \\
6 \\
14 \\
13 \\
10 \\
12 \\
11 \\
11 \\
9 \\
6 \\
14 \\
12 \\
13 \\
10 \\
12 \\
8 \\
11 \\
12\end{array}$ & $\begin{array}{l}0.14 \\
0.08 \\
0.12 \\
0.20 \\
0.15 \\
0.27 \\
0.09 \\
0.16 \\
0.06 \\
0.19 \\
0.14 \\
0.09 \\
0.17 \\
0.05 \\
0.26 \\
0.10 \\
0.06 \\
0.06 \\
0.15 \\
0.06 \\
0.09 \\
0.14 \\
0.10 \\
0.38\end{array}$ & $\begin{array}{l}0.14 \\
0.29 \\
0.31 \\
0.38 \\
0.65 \\
0.26 \\
0.30 \\
0.07 \\
0.48 \\
0.42 \\
0.59 \\
0.39 \\
0.63 \\
0.30 \\
0.85 \\
0.58 \\
0.54 \\
0.38 \\
0.28 \\
0.50 \\
0.42 \\
0.43 \\
0.50 \\
0.86\end{array}$ & $\begin{array}{l}106 \\
173 \\
251 \\
190 \\
174 \\
268 \\
167 \\
143 \\
236 \\
309 \\
116 \\
520 \\
254 \\
125 \\
138 \\
104 \\
82 \\
41 \\
350 \\
196 \\
290 \\
184 \\
133 \\
168\end{array}$ & $\begin{array}{l}0.65 \\
0.58 \\
0.27 \\
0.60 \\
1.00 \\
0.66 \\
0.15 \\
0.13 \\
0.35 \\
0.22 \\
0.32 \\
0.70 \\
0.45 \\
0.32 \\
0.83 \\
0.31 \\
0.51 \\
0.16 \\
0.42 \\
0.15 \\
0.62 \\
0.22 \\
0.20 \\
0.32\end{array}$ \\
\hline
\end{tabular}


was present in only one patient (Case 13), a group A case with healed osteomalacia and renal failure.

The normal range of the $\mathrm{Ca} \times \mathrm{P}$ products was established by us on 40 normal subjects. Only five in group $A$ and two in group B had plasma $\mathrm{Ca} \times \mathrm{P}$ products below the lower normal limit (23), but nearly all the cases in both groups had products below our normal mean (34). Case 13 had a past history of osteomalacia and Case 7 had active osteomalacia.

Calcium excretion, expressed in mg./24 hours, tended to be low in group A, with a few exceptions, and normal in group B. It was less than $100 \mathrm{mg} . / 24$ hours in 11 group $A$ cases and two group B cases. Values over $300 \mathrm{mg} . / 24$ hours were observed in two group A and three group B cases. There was a highly significant correlation between urinary calcium and creatinine clearance in both groups (group $\mathrm{A}, \mathrm{r}=0.63$; group $\mathrm{B}, \mathrm{r}=0.52$ ) (Fig. 6).

Calcium excretion ( $\mathrm{Ca}_{\mathrm{E}}$ ) expressed in $\mathrm{mg} . / 100 \mathrm{ml}$. of glomerular filtrate (G.F.) (Peacock and Nordin, 1968) was generally above the normal fasting mean (0.08) in both groups, and above the upper limit $(0.14)$ in 12 of group $A$ and nine of group $B$.
Phosphorus excretion $\left(\mathbf{P}_{\mathbf{E}}\right)$ expressed in $\mathrm{mg} . / 100 \mathrm{ml}$. of G.F. (Nordin and Bulusu, 1968), is shown in relation to the corresponding serum phosphorus in Fig. 7. All except two of group B values were within the normal range, but in the majority of group A cases phosphorus excretion was abnormally high relative to the serum phosphorus level.

Serum alkaline phosphatase values were within the normal range in all group B cases and were raised in three group A cases, but one of these (Case 24) had Paget's disease.

Urinary citrate tended to be low in group $A$ and normal in group B (Tables III and IV). Citrate/creatinine ratios of less than 0.20 were found in 14 group $A$ and four group B cases. There was no significant correlation between the citrate/ creatinine ratio and either the creatinine clearance or the serum bicarbonate.

\section{Discussion}

Renal tubular acidosis may be defined as a condition in which there is an acidification defect which tends to cause a metabolic hyperchloraemic acidosis. This definition clearly includes

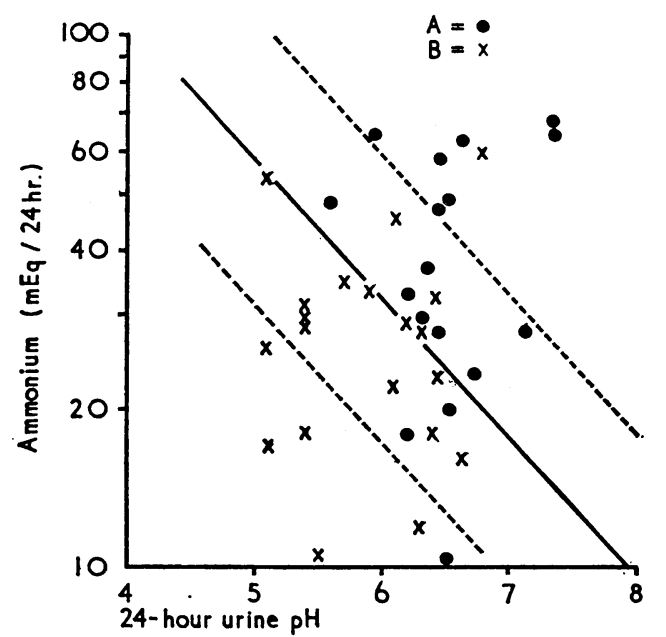

FIG. 4

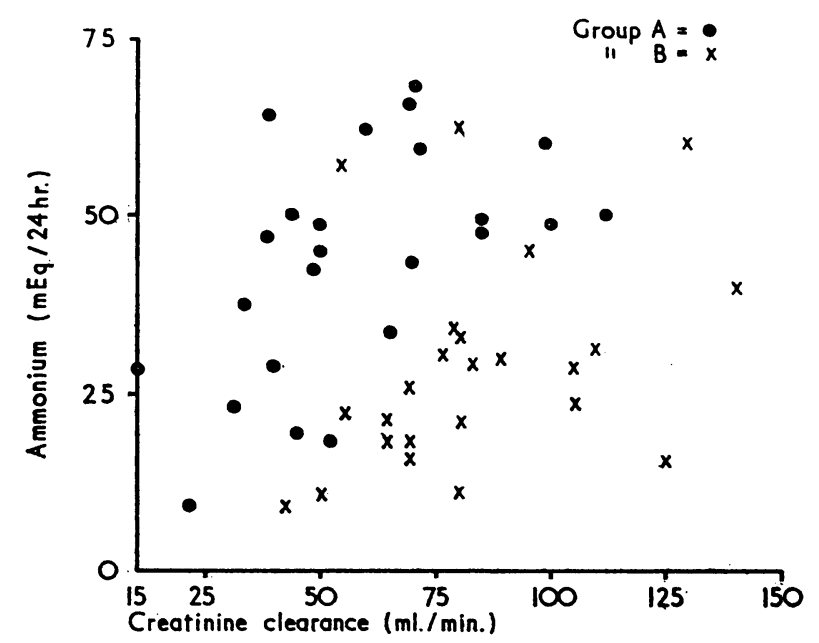

FIG. 5

FIG. 4.-Relation between ammonium excretion in $\mathrm{mEq} / 24$ hours and the 24-hour urinary $p H$ in group $A$ and group B. The regression line and $95 \%$ limits for normals are adapted from the data of Wrong and Davies (1959). FIG. 5.Relation between ammonium excretion in $\mathrm{mEq} / 24$ hours and endogenous creatinine clearance in ml./minute in group $\mathrm{A}$ and group $\mathrm{B}$.

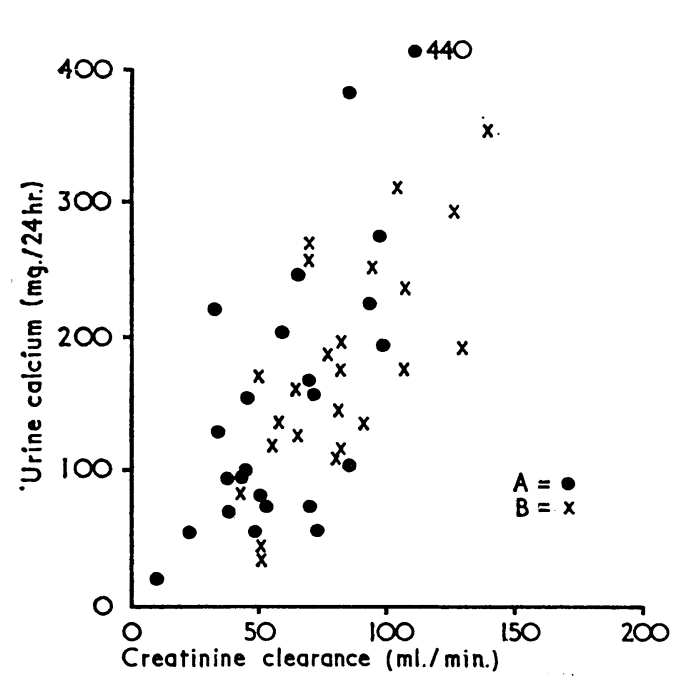

Fig. 6

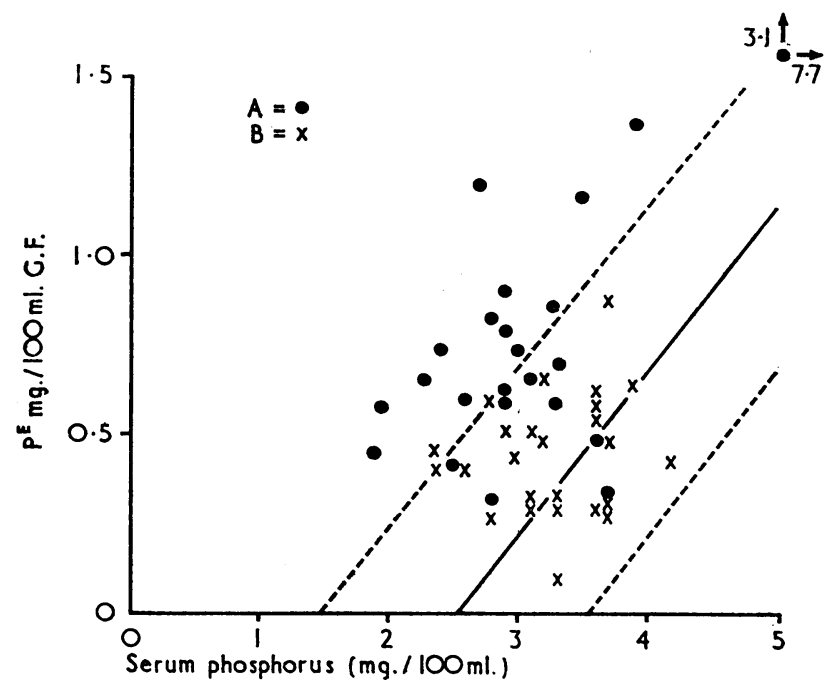

FIG. 7

PIG. 6.-Relation between urinary calcium excretion in $\mathrm{mg} . / 24$ hours and endogenous creatinine clearance in ml./minute in group $A$ and group B. FIG. 7.- Relation between phosphorus excretion in mg./100 ml. of glomerular filtrate and the serum inorganic phosphorus in $\mathrm{mg} . / 100 \mathrm{ml}$. in group A and group B. The regression lines indicate the mean and $95 \%$ confidence limits of our normal range (Nordin and Bulusu, $1 y, 08$ ). 
patients who do not have a frank acidosis, and most of our cases came into this category.

The actual defect, and the one met with here, is an inability of the distal tubule to achieve the normal sharp hydrogen-ion gradient between extracellular fluid and urine. However, two additional causes of a hyperchloraemic acidosis are possible. One of these is a bicarbonate-losing state. A few cases of this have been well documented (Latner and Burnard, 1950 ; Schwartz and Relman, 1957), and it is probably the abnormality responsible for hyperchloraemic acidosis in patients who can acidify their urine when their acidosis is sufficiently severe. Secondly, it is also possible to conceive of a primary failure of tubular ammonium production in the absence of glomerular damage which would also lead to a hyperchloraemic acidosis with an acid urine. The case reported by McCance, Matheson, Gresham, and Elkinton (1960) may be of this type. A mild form of this defect may also be responsible for the persistently acid urines associated with the formation of uric acid stones (Rapoport, Crassweller, Husdan, From, Zweig, and Johnson, 1967).

The term " renal tubular acidosis" therefore implies that the lesion is purely or predominantly tubular. It is true that all renal acidosis ultimately arises from a tubular defect, as Schwartz and Relman (1957) have pointed out, but the acidosis of general renal failure is accompanied by many other features of renal insufficiency. This type of acidosis is mainly due to a reduced production of ammonia (Albright and Reifenstein, 1948 ; Milne, 1951 ; Wrong and Davies, 1959), though there may also be a decrease in titratable acid as a high urine flow through the remaining nephrons prevents the development of a very acid urine. In the patient with renal tubular acidosis, an inability to acidify the urine below pH 6 as against 5 reduces the effective excretion of titratable acidity by about $5 \mathrm{mEq} /$ day, which is easily offset by a corresponding increase in ammonium production provided there is adequate renal parenchyma.

Renal tubular acidosis is not therefore necessarily associated with chronic metabolic acidosis, though there is diminished capacity to compensate for any acid load that is imposed; this is the incomplete syndrome of renal tubular acidosis in the terminology of Wrong and Davies (1959). In only five of our group A cases was there a definite metabolic acidosis, as judged from plasma $\mathrm{HCO}_{3}$; in nine cases the plasma $\mathrm{HCO}_{3}$ was definitely normal. However, the excretion of titratable acid was low in all but two cases and below the lower limit of normal in half of these. In most of the controls it was normal. Ammonium production, on the other hand, tended to be higher in group A than in group B, but the spread was wide in both groups. Thus from the diagnostic point of view the ratio titratable acidity/ammonium separates them most satisfactorily and the lower normal limit of 0.4 suggested by Nordin and Smith (1965) seems to be reasonably valid. A high titratable acidity/ammonium ratio might be expected in association with a reduced glomerular filtration rate, and in fact four of the five cases in group B with a raised titratable acidity/ammonium ratio had low creatinine clearances $(43,55,56$, and $65 \mathrm{ml} . /$ min.). Another feature of group $A$ cases is that they tend to have a raised ammonium excretion relative to the urine $\mathrm{pH}$, as pointed out by Wrong and Davies (1959). Furthermore, group $\mathrm{A}$ cases with the highest ammonium excretion relative to the urine $p \mathrm{H}$ are those with the highest creatinine clearances and, conversely, the group B cases with the lowest ammonium excretion relative to urine $\mathrm{pH}$ have the lowest creatinine clearances. This is in line with the observation of Wrong and Davies (1959) and Giovannetti and Pasero (1959) that ammonia production correlates with the glomerular filtration rate. However, there is clearly a higher output of ammonium for a given creatinine clearance in group A cases than among group B cases (Fig. 5).

Thus the ammonium excretion of group $\mathbf{A}$ cases is high relative to both urine $\mathrm{pH}$ and glomerular filtration rate. The most likely explanation is the intermittent, if not necessarily continuous, metabolic acidosis to which these cases are subject under any acid stress, since it is well established that production of ammonium is enhanced in chronic acidosis (Wrong and Davies, 1959).

It is very unlikely that the ammonium values were elevated by urea-splitting organisms in the urine because the preservatives used in the containers were found effective even when cultures of various Proteus species were artificially introduced into urines. Moreover, proteus infection was as common among the group $B$ cases as among group A, and antibiotic therapy had in most instances controlled the urinary tract infection at the time of urine collection.

\section{Chronic Pyelonephritis}

In most previous series of renal tubular acidosis pyelonephritis has been an associated feature of some of the cases (Albright and Reifenstein, 1948) but has not been seriously considered as the primary cause of the condition. It is only in the last few years that the possible role of chronic pyelonephritis in the pathogenesis of renal tubular acidosis has been appreciated (Wrong, 1965), but the number of well-documented cases is very few and most of them are probably bicarbonate losers (Lathem, 1958). About $20 \%$ of patients seen in our stone clinic were found to have pyelonephritis, and some $25 \%$ of these were found to have renal tubular acidosis. Renal tubular acidosis was not found in the absence of infection and was presumably secondary to it, the determining factors probably being the duration and severity of the infection. Thus group A cases had a significantly longer history of pyelonephritis $(P<0.05)$ than group $B$ cases, and in most of the group A cases symptoms of urinary tract infection were a troublesome feature of their condition. In some cases, however, renal tubular acidosis was present after a relatively short history of urinary tract infection, and we believe this was due to the varying extent and severity of the renal involvement. $E$. coli and Proteus species were the common pathogens cultured, but they occurred with equal frequency in both groups.

Though by definition the cases in group B could acidify their urine below pH 5.4 half of them could not get below 5, which most normal subjects can achieve. This suggests that they are at an earlier stage in the development of renal tubular acidosis secondary to pyelonephritis. It is of interest that six of the seven patients with unilateral renal disease (as judged radiologically) could achieve a $\mathrm{pH}$ of 5 or less. Most of those with bilateral renal disease could not.

It is well known that a defect in renal concentrating power may develop rapidly in the presence of active urinary tract

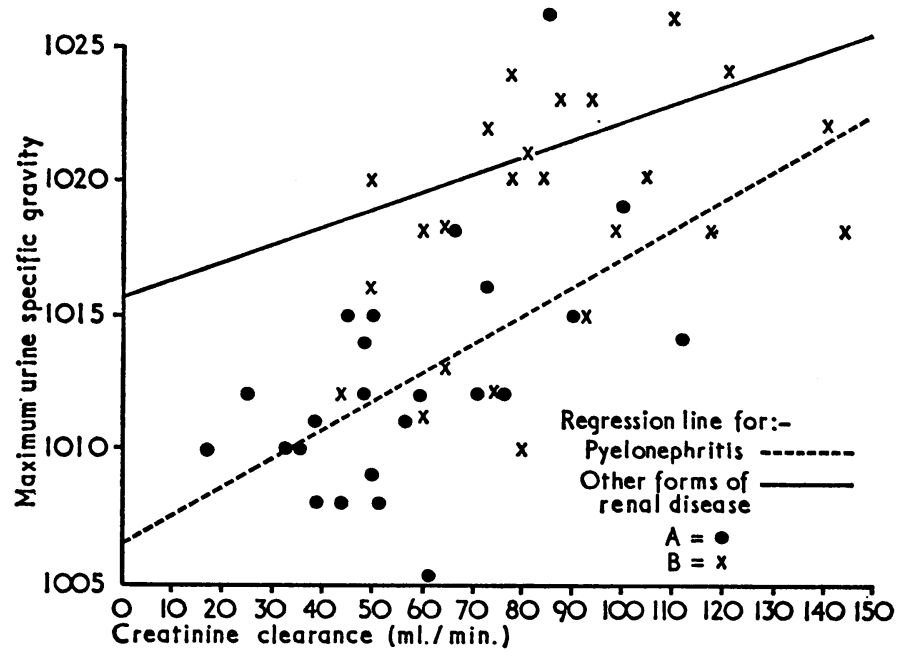

FIG. 8.-Relation between maximum urine specific gravity after 18 hours' fluid deprivation and creatinine clearance in $\mathrm{ml} /$ /minute in group $A$ and group B. The interrupted regression line is that for pyelonephritis and the solid line that for other forms of renal disease (Brod, 1956). 
infection (Kaitz, 1961), and Brod (1956) has shown that in chronic pyelonephritis the impairment of concentrating power is more severe relative to the glomerular filtration rate than in other forms of renal disease. Concentrating power was moderately reduced in both our groups, but more severely in group A cases. The relation of concentrating power to creatinine clearance in all our group A cases and about half our group B cases corresponded to Brod's regression line for pyelonephritis (Fig. 8). It is therefore likely that infection was responsible both for the diminished concentrating ability and for the defect in acidifying power. This thesis is further supported by the fact that one patient with persistent urinary tract infection developed a failure to acidify her urine during a 12-month period of observation.

\section{History of Stone Disease}

The mean length of history of stone disease was essentially the same in the two groups (eight and six years). In most of the group A cases, and many of the group B cases, the history of urinary tract infection preceded the history of stone disease. There were, however, some cases in group B where infection probably developed secondarily around an existing stone. A characteristic feature of the patients with renal tubular acidosis was the presence of bilateral staghorn calculi which had rapidly re-formed after surgical removal. Elimination of infection by energetic long-term treatment with appropriate antibiotics has prevented such recurrence in at least five cases. There has been no measurable change in renal tubular function in these patients, so that infection was presumably playing a major part in their stone formation. Moreover, though most of the group A patients gave a history of overt attacks of urinary tract infection for many years, early investigations, available in a few cases, had shown no evidence of renal stone.

The implication is therefore that rapid growth of staghorn calculi occurs with renal tubular acidosis in the presence of active infection. No stone ever occurred in a kidney judged radiologically normal. Staghorn calculi or clumps of mediumsized stones were typical of group A cases and occurred in over half the group B cases. Though small stones were often passed by patients in both groups, multiple small stones lying in the renal pelvis or renal parenchyma were uncommon (four cases in group A, one case in group B).

Chemical analysis showed that in both groups the stones were predominantly mixed magnesium ammonium phosphate and calcium phosphate. In some of the group B cases, however, calcium phosphate stones occurred without magnesium ammonium phosphate. As a working hypothesis, therefore, it might be suggested that simple elevation of the urine $p H$ leads to calcium phosphate precipitation whereas a high urine $\mathrm{pH}$ with a high urinary ammonium results in formation of magnesium ammonium phosphate stones (Robertson, Peacock, and Nordin, 1968). The occurrence of calcium phosphate stones without magnesium ammonium phosphate in group B also suggests that these cases represent an earlier stage in the process than group $\mathrm{A}$, in whom magnesium ammonium phosphate was always present. The calcium oxalate in a few calculi is not easily explained, but it may have antedated the infection in these particular cases.

Thus in many respects the groups merge into each other, the division between them being an arbitrary one. It may well be that some of the group B cases with unilateral staghorn calculi already have impaired acidifying power in the affected kidney.

\section{Serum Values}

Theoretically, a patient with renal tubular acidosis must also have a renal tubular leak of sodium, but only in so far as there is decreased sodium-hydrogen ion exchange in the distal tubule.
However, as has already been pointed out, this loss is in theory of the order of only $5 \mathrm{mEq} /$ day, an amount that is easily compensated by dietary intake or by conservation at the gut level (Shields, 1966). Serum sodium concentrations were normal in both groups, and there was no evidence to suggest sodium deficiency in any of the patients. In classical renal tubular acidosis a potassium-losing state is common. However, serum potassium was consistently normal in our cases and there were never any clinical findings to suggest significant disturbances of potassium metabolism. Though gastrointestinal mechanisms might mask the effects of minor renal abnormalities of potassium handling, our impression is that potassium excretion by the renal tubule is relatively unaffected in renal tubular acidosis acquired as a result of pyelonephritis.

In our series there were very few instances of overt acidosis, for reasons already suggested (compensation by ammonium excretion), and no consistent abnormality of serum chloride or bicarbonate. However, it was noteworthy that those patients with the lowest plasma bicarbonate levels did in fact have hyperchloraemia, as would be expected if this acidosis were predominantly tubular in origin. It was a characteristic feature of these cases that the severity of their metabolic acidosis appeared to be disproportionate to their degree of renal failure.

Serum calcium values tend to fall within the normal range in the great majority of patients in both groups. There were four cases of hypocalcaemia and four of hypophosphataemia in group A and two of hypocalcaemia and two of hypophosphataemia in group B. In only one case was there both hypocalcaemia and hypophosphataemia, and this patient also had a raised serum alkaline phosphatase and was regarded as a case of osteomalacia. The serum $\mathrm{Ca} \times \mathrm{P}$ product fell within our normal range ( 23 to 45 ) in all but six group A cases and in all but two of the controls. However, there was a clear tendency for the products to fall in the lower half of our normal range in both groups, and in all but three group $\mathrm{A}$ cases the $\mathrm{Ca} \times \mathbf{P}$ product was below our normal mean. This tendency was mainly attributable to a tendency to hypophosphataemia in this group as a whole, which is particularly interesting in view of the many cases of renal failure among them. Apart from the case of osteomalacia already referred to, there was one other patient with a past history of osteomalacia in whom the alkaline phosphatase was still raised. There was one case with a high alkaline phosphatase associated with Paget's disease (Case 24). In the control series there were no definite elevations of alkaline phosphatase but a few marginal values in the range 12-14 units/ $100 \mathrm{ml}$., which we regard as of doubtful significance. Thus there was very little evidence of clinical osteomalacia in group A except in two severe cases of renal tubular acidosis, both in women.

The tendency to hypophosphataemia referred to above was associated with and presumably secondary to hyperphosphaturia. The phosphorus excreted per $100 \mathrm{ml}$. of glomerular filtrate was raised out of proportion to the serum phosphorus level in the great majority of group A cases and in only two group B cases (Fig. 7). This could be due to the secondary hyperparathyroidism which is a feature of renal failure and is believed to contribute to phophorus homoeostasis as renal function deteriorates (Riddick and Reiss, 1962). However, it seems curious that this secondary hyperparathyroidism, if such it is, should not only prevent the elevation of serum phosphorus, which would otherwise occur in renal failure, but should actually produce hypophosphataemia, and the question arises whether some other factor, such as tubular damage or a tendency to metabolic acidosis, may not contribute to the hyperphosphaturia as well. It has been shown by Morrin (1965) that the hyperphosphaturia of renal failure can be suppressed by calcium infusion and so is presumably due to secondary hyperparathyroidism. We do not know whether this is also true of the hyperphosphaturia of renal tubular acidosis, though some preliminary work that we have done suggests that it is not (Nordin and Smith, 1967). 


\section{Calcium and Citrate Excretion}

Calcium excretion expressed in absolute terms (mg./24 hours) covered a wide range in both groups of cases and could not be described as consistently reduced or raised in either group. However, a clear correlation was established between creatinine clearance and urinary calcium excretion (Fig. 6), the correlation between these two criteria being highly significant in each group individually. This confirms the well-known fact that urinary calcium is greatly influenced by the glomerular filtration rate (Nordin et al., 1967). However, the regression of calcium excretion on creatinine clearance was steeper in the group A series because of their tendency to metabolic acidosis; there is good evidence that metabolic acidosis reduces tubular reabsorption of calcium (Lemann, Litzow, and Lennon, 1967).

Citrate excretion tended to be low or very low in group A and relatively normal in group B. The normal range of citrate excretion is very wide, and when expressed as a ratio to creatinine extends from about 0.2 to 1.0 (Nordin and Smith, 1965). With very few exceptions citrate excretion in group $B$ was normal, but in group A nearly all the values were towards the bottom of the normal range and some well below it. In two cases there was no measurable citric acid in the urine. There are at least three possible causes of the reduced citrate output that is known to be a feature of renal stone disease. It has been suggested that it is attributable to metabolism of citric acid in the urine by bacteria (Conway, Maitland, and Rennie, 1949). We have previously expressed the view that this is unlikely to be the explanation, since we have found no difference in the citrate output of infected and non-infected stone-formers (Nordin and Smith, 1963). This is confirmed in the present series, where both the low urinary citrates of group A cases and the normal urinary citrates of group $B$ were associated with chronic pyelonephritis.

The second possible explanation is that impaired renal function lowers citrate output in the same way as it lowers the output of, for instance, calcium. This view has been put forward by Hodgkinson (1962). It is true that our group A cases tended to have lower glomerular filtration rates than our group B cases, but inspection of the data shows that many of the low urine citrate values were obtained in cases with relatively normal renal function, and vice versa.

The third possible explanation of hypocitruria is metabolic acidosis. It is known (Dedmon and Wrong, 1962) that urine citrate is related to acid/base status, that metabolic acidosis tends to lower and metabolic alkalosis to increase the excretion of citrate in the urine, and that urinary citrate excretion tends to reflect the degree of metabolic acidosis rather than the level of renal function in cases where these two can be distinguished (Nordin and Smith, 1963). The same appears to be true of our present data in that the patients with the most severe metabolic acidosis are clearly those with the lowest urinary citrate output, and we would suggest that the tendency to hypocitruria in group $\mathrm{A}$ as a whole reflects the tendency towards metabolic acidosis of this group of cases even though the actual degree of metabolic acidosis found at the time of observation was usually very slight.

\section{Conclusions}

We conclude that chronic pyelonephritis may give rise to a defect of renal acidifying power indistinguishable from classical renal tubular hyperchloraemic acidosis. In the majority of cases of chronic pyelonephritis with this defect, however, the defect is not severe enough to cause a metabolic acidosis. The condition is frequently associated with renal stone disease and is found in a substantial proportion of patients in whom recurrent nephrolithiasis is associated with urinary tract infection. The order in which infection, stone disease, and tubular acidosis develop cannot be stated with certainty, but the present series suggests that infection is the initiating factor, that this infection (possibly by virtue of the alkalinity of the urine combined with its high ammonium content) gives rise to stone formation, and that ultimately chronic distal tubular damage leads to an acidifying defect. This creates what is in effect a vicious circle in which a chronically alkaline urine promotes stone growth, the presence of stone perpetuates the infection, and the infection aggravates the distal tubular disease. Many or most of these patients have some degree of renal failure, but their characteristic feature in the later stages is a degree of metabolic acidosis disproportionate to their degree of impairment of glomerular function with a tendency to the formation of large staghorn calculi which quickly recur after operation unless the infection is rigorously controlled. The syndrome does not generally present with either hypokalaemia or bone disease, and in this respect differs perhaps from classical renal tubular acidosis; but this may of course be because it represents a milder form of the renal tubular acidosis syndrome.

\section{Summary}

Renal acidifying power was tested in about 600 patients with renal stone disease, the short ammonium chloride loading test of Davies and Wrong (1957) being used. Twenty-four patients were unable to acidify their urine to $\mathrm{pH} 5.4$ (group A); all of them had evidence of chronic pyelonephritis. These patients are compared with 24 stone patients with pyelonephritis and normal acidifying power (group B). The group A patients tended to have a longer history of pyelonephritis than the group B patients and were more liable to bilateral stone formation. Their excretion of titratable acid tended to be lower and their excretion of ammonium higher than in group B. Concentrating power tended to be more impaired in group $A$ than in group B cases, but was low relative to creatinine clearance in both groups.

Only five group A cases and no group B cases were actually acidotic at the time of observation and electrolytes were essentially normal in both groups. Serum calcium and phosphorus were normal in both groups, except in two cases of osteomalacia in group $\mathrm{A}$, but the serum $\mathrm{Ca} \times \mathbf{P}$ products tended to be low. Serum alkaline phosphatase was raised in those two cases and in one case with Paget's disease.

Phosphate excretion tended to be high relative to serum phosphate in group A. Calcium output per 24 hours was related to creatinine clearance in both groups but tended to be lower in group A than in group B. Calcium excretion per $100 \mathrm{ml}$. of glomerular filtrate tended to be raised in both groups. Urinary citrate tended to be low in group A.

It is concluded that a form of acidifying defect indistinguishable from that in congenital renal tubular acidosis, but generally not accompanied by overt acidosis, can be acquired from pyelonephritis associated with stone disease. Postoperative long-term chemotherapy in a few cases has so far prevented stone recurrence.

\section{REFERENCES}

Albright, F., Consolazio, W. V., Coombs, F. S., Sulkowitch, H. W., and Talbot, J. H. (1940). Bull Fohns Hopk. Hosp., 66, 7.

Albright, F., and Reifenstein, E. C. (1948). The Parathyroids and Metabolic Bone Disease. Baltimore.

Berlyne, G. M. (1961). Quart. F. Med., 30, 339.

Brod, J. (1956). Lancet, 1, 973.

Butler, A. M., Wilson, J. L., and Farber, S. (1936). F. Pediat., 8, 489.

Chaney, A. L., and Marbach, E. P. (1962). Clin. Ckem., 8, 130.

Conway, N. S., Maitland, A. I. L., and Rennie, J. B. (1949). Brit. Y. Urol., 21, 30.

Cotran, R. S. (1965). In Progress in Pyelonephritis, edited by E. H. Kass. Philadelphia.

Davies, H. E. F., and Wrong, O. (1957). Lancet, 2, 625.

Dawborn, J. K., Fairley, K. F., Kincaid-Smith, P., and King, W. E. (1966). Quart. F. Med., 35, 69.

Dedmon, R. E., and Wrong, O. (1962). Clin. Sci., 22, 19

Edwards, D. (1965). In Progress in Pyelonephritis, edited by E. K. Kass. Philadelphia.

Ettinger, R. H., Goldbaum, L. R., and Smith, L. H., jun. (1952). \%. biol. Chem., 199, 531 
Giovannetti, S., and Pasero, G. (1959). Minerva nefrol., 6, 119.

Hodgkinson, A. (1962). Clin. Sci., 23, 203

Huth, E. J., Webster, G. D., and Elkinton, J. R. (1960). Amer. F. Med., 29,586 .

Jackson, W. P. U., and Linder, G. C. (1953). Quart. F. Med., 22, 133.

Kaitz, A. L. (1961). F. clin. Invest., 40, 1331 .

Kleeman, C. R., Hewitt, W. L., and Guze, L. B. (1960). Medicine (Baltimore), 39,3

Latner, A. L., and Burnard, E. D. (1950). Quart. F. Med., 19, 285.

Lathem, W. (1958). New Engl. F. Med., 258, 1031.

Lemann, J., Litzow, J. R., and Lennon, E. J. (1967). F. clin. Invest., 46, 1318 .

Little, P. J., and de Wardener, H. E. (1962). Lancet, 1, 1145.

McCance, R. A., Matheson, W. J., Gresham, G. A., and Elkinton, J. R. (1960). Arch. Dis. Childh., 35, 240.

Miles, B. E., Paton, A., and de Wardener, H. E. (1954). Brit. med. F., 2, 901 .

Milne, M. D. (1951). The Action of Parathyroid Hormone and the Metabolic Changes Following Mobilization of Bone Salt. Thesis, University of Manchester.

Morrin, P. A. F. (1965). Metabolism, 14, 674.

Nordin, B. E. C., and Bulusu, L. (1968). Postgrad. med. 7., 44, 93.
Nordin, B. E. C., Hodgkinson, A., and Peacock, M. (1967). Clin. Orthop., 52, 293.

Nordin, B. E. C., and Smith, D. A. (1963). Brit. F. Urol., 35, 438.

Nordin, B. E. C., and Smith, D. A. (1965). Diagnostic Procedures in Disorders of Calcium Metabolism. London.

Nordin, B. E. C., and Smith, D. A. (1967). In L'Osteomalacie, edited by D. J. Hioco. Paris.

Peacock, M., and Nordin, B. E. C. (1968). f. clin. Path. In press.

Pitts, H. H., jun., Schulte, J. W., and Smith, D. R. (1955). F. Urol. (Baltimore), 73, 208.

Rapoport, A., Crassweller, P. O., Husdan, H., From, G. L. A., Zweig, M., and Johnson, M. D. (1967). Metabolism, 16, 176.

Riddick, F. A., and Reiss, E. (1962). Ann. intern. Med., 56, 183.

Robertson, W. G., Peacock, M., and Nordin, B. E. C. (1968). Clin. Sci. In press.

Schwartz, W. B., and Relman, A. S. (1957). New Engl. F. Med., 256 , 1184 .

Shields, R. (1966). In Postgraduate Gastro-Enterology, edited by R. J. Thomson and I. G. Gillespie. London.

Wootton, I. D. P., and King, E. J. (1953). Lancet, 1, 470.

Wrong, $\mathrm{O}$ (1965) $\%$ clin Path $18,520$.

Wrong, O., and Davies, I. E. F.'(1959). Quart. F. Med., 28, 259.

\title{
Effect of Calcium Administration and Deprivation on Serum and Urine Calcium in Stone-forming and Control Subjects
}

\author{
M. PEACOCK,* M.B., CH.B., M.R.C.P. ; F. KNOWLES,* F.I.M.L.T. ; B. E. C. NORDIN,* M.D., PH.D., F.R.C.P.
}

Brit. med. F., 1968, 2. 729-731

Idiopathic hypercalciuria is a syndrome characterized by a raised urinary calcium associated with normocalcaemia and a tendency to hypophosphataemia (Albright et al., 1953; Harrison, 1959 ; Edwards and Hodgkinson, 1965). Hypercalciuria is common in patients with renal stone disease (Flocks, 1939 ; Hodgkinson and Pyrah, 1958), but is also present in a proportion of the normal population (Knapp, 1947 ; Hodgkinson and Pyrah, 1958; Watson and Dale, 1966; Nordin et al., 1967), the exact prevalence depending on how it is defined.

The cause of idiopathic hypercalciuria has not been established, but increased calcium absorption is known to be a feature of the condition (Henneman et al., 1958 ; Hodgkinson, 1961). Some workers believe this hyperabsorption of calcium to be primary, while others regard it as a response to increased calcium excretion (Jackson and Dancaster, 1959). In previous papers we have shown that tubular reabsorption of calcium is generally normal in idiopathic hypercalciuria (Nordin et al., 1967 ; Peacock and Nordin, 1968). The present paper gives further data on the relation between calcium ingested, plasma calcium, and urinary calcium in normal and hypercalciuric subjects and describes a simple prucedure for the diagnosis of the condition.

\section{Clinical Material and Methods}

The patients consisted of nine male idiopathic renal stoneformers who showed persistent hypercalciuria on a free diet according to the definition of Hodgkinson and Pyrah (1958)that is, over $300 \mathrm{mg}$. daily. Their ages ranged from 24 to 54 years. In no case was there evidence of renal failure, systemic acidosis, or endocrine disease. The controls consisted of nine healthy males, all members of staff, aged 17 to 40 years, none of whom was hypercalciuric.

The hypercalciuric patients were first studied in the nonfasting state when simultaneous samples of blood and urine were obtained for measurement of calcium and creatinine. Subsequently the patients were admitted to the ward fasting and observed for one day of total starvation. Tap-water was given at a rate of half a pint $(285 \mathrm{ml}$.) an hour to ensure adequate urine flow and bladder emptying. Urine samples were collected every two hours and blood was taken at the midpoint of each collection. The test usually started at 8 a.m. and was completed by 6 p.m. On another day the same patients were again admitted to the ward after an overnight fast. A two-hour specimen of urine was collected with a blood sample taken at the midpoint and the patients were then given an oral load of calcium (100 mg. $/ \mathrm{kg}$.) as a calcium citrate suspension over a period of 15 minutes. Urine samples were collected for eight hours, hourly for the first four hours and two-hourly thereafter. Blood samples were taken at the midpoint of each urine collection. A light calcium-free breakfast was allowed half an hour after the calcium load and a light low-calcium lunch three hours later. The patients were not confined to bed. The calcium citrate was well tolerated by all of them and did not cause vomiting or diarrhoea.

In the nine controls blood and urine samples were obtained after an overnight fast for comparison with the stone cases, and the calcium citrate load was given and samples were obtained as described for the nine cases of idiopathic hypercalciuria.

Calcium was estimated with $o$-cresolphthalein complexone in serum and urine by AutoAnalyzer techniques as modified by Knowles (1968). Creatinine was estimated with picric acid by the standard AutoAnalyzer method (Technicon Methods Manual, N-11b).

Urine calcium is expressed as calcium excreted per $100 \mathrm{ml}$. of glomerular filtrate $\left(\mathrm{Ca}_{\mathrm{E}}\right)$, which is calculated as follows (Nordin et al., 1967 ; Peacock and Nordin, 1968):

$\mathrm{Ca}_{\mathrm{E}}$ (mg. $/ 100 \mathrm{ml}$. of G.F.) = urine calcium $\times$ plasma creatinine when all concentrations are expressed in $\mathrm{mg} . / 100 \mathrm{ml}$. The range of plasma creatinine was the same in stone-formers and controls (0.7-1.1 mg./100 ml.).

* Medical Research Council, Mineral Metabolism Research Unit, the General Infirmary, Leeds. 